\title{
TALENT MANAGEMENT AND ITS USE BY ORGANIZATIONS IN THE MORAVIAN-SILESIAN REGION
}

\author{
Petra Horváthová, Marie Mikušová
}

\section{Key words:}

talent, talent management, acquisition, development, retention, usage, Moravian-Silesian region

\begin{abstract}
The article is aimed not only, on the basis of available theoretical information, at describing the nature, significance, benefits and particular processes of talents management (their acquisition, development and retention) but also at bringing information on the scope and the level of use of talent management by organizations in one of the Czech Republic regions, in the Moravian-Silesian Region. On the basis of data acquired by a questionnaire survey it has been found out that organizations in the above-mentioned region are implementing the system of talent management on a small scale: this approach is used by $3.8 \%$ of organizations only that is 9 from $237(100 \%)$ of the approached respondents. The main reasons why this approach is not used is either that organizations have no knowledge of it or there is lack of financial and personnel resources. Another aim of the article is to bring recommendations suggested by the authors for a wider application of talent management in the Czech practice.
\end{abstract}

\section{Introduction}

The wish of every organization is to achieve in advance stated objectives and to fulfill its tasks successfully. In order to be able to carry out its intentions, the organization has to employ all its resources - people, materials, technique and technologies, capital as well as methods - as efficiently as possible. It is not financial means, modern and efficient techniques and technologies but people, efficient employees who appear to be the main competitive edge. Companies which place a great importance on employees' personal creativity and in spite of their size they decrease the level of formalization of communication, relationships and management thus will attain a position of leaders in their segment.

Organizations that want to survive and grow, and overtake their existing competition and substantially increase their added value in growing competition have to attract, cultivate, retain, but especially develop quality, namely talented employees, and, as long as possible, especially those who are extraordinary talented. However, this concerns a relatively small and ultimate group of the most talented potential employees and that is why a struggle of organizations for these employees is becoming considerably harsh. Stock of the most capable people in the current population is rather limited [6]. From that fact it clearly follows for organizations that in the interest of their competitiveness they have to fight for these limited sources and in the interest of their victory in this fight to find and employ the most efficient instruments [5].

A follow-up care for talented employees, efforts aimed at their development and their retention in the organization should also go without saying.

\section{The basic concepts}

A concept of talent and a concept of talent management rank among the basic concepts in the specified field. What is talent? Who can be labeled as a talent? What should be the idea of 
'talent management' concept? To answer these basic questions, however, is not easy. Both at the academic ground and in practice the discussion of how to define a talent and how to determine talent management continues.

Some experts consider as a talent such an extraordinarily competent employee with a high potential who can significantly influence organization's performance and they think that talent management concerns only key individuals that is competent people heading for holding higher or top posts [8]. This attitude to who that may be labeled as a talent prevails also in this country, the Czech Republic.

Yet, some experts say that as a talent can be practically considered anybody who may contribute to the achievement of organization's goals that talent management should not be restricted to a few favored individuals only. To what extent an individual will contribute to the fulfillment of organization's tasks depends on the scope of attention the organization will pay to the development of their talent.

One of the most usual definitions describes a talented individual as a man who brings both a high performance and shows a high potential. Some organizations focus on the ability of being promoted and as a talent they consider such employees who bring on one hand a high performance and are highly promotional on the other hand. Other definitions, on the contrary, focus on inputs or competences.

And how should be a concept of talent management defined? A prevailing part of the professional public agrees that the system in question is the system of acquisition, retention and development of talents.

Some authors, for example, consider as talent management the use of a mutually interconnected set of activities that are to ensure that the organization will attract, retain, motivate and develop abilities of talented people that it needs at present and will need in the future either [1]. The aim is to ensure a flow of talents and to realize that talents are the main resource of organization.

The authors of this paper consider a talent as an individual who brings both a high performance and shows a high potential; a mutually interconnected set of organization's activities whose task is to acquire, develop, motivate and retain talented employees needed for the fulfillment of both current and future business objectives she thinks talent management.

\section{Significance and benefits of talent management}

In the life of organization a number of situations occur which as long as they are not solved have a negative impact on working of the organization. Successful managing of the issues of human resources management, their development, deployment and interconnection of their important knowledge appear to be a crucial field. This is and it will be crucial for the differentiation of prosperous organizations from others.

Not only representatives of foreign organizations but also representatives of Czech firms are beginning to realize that human resources are today more crucial than in any other time, they are beginning e.g. to understand the importance and advantages of work with talent as one of 
instruments of problematic situations solution, they are aware of its benefits for the organization.

By means of talent management, by means of systematic work with talents the following situations and strategic issues, for example, can be solved - the issue of identification and needs of talents in connection with trading priorities; difficulties with filling the most important positions appear in the organization, there is lack of skilled people on the market; a process of acquiring employees in the organization is successful but it turns out to be difficult to retain talented employees there; it is not possible efficiently to find talents and to identify employees with a high potential; it is difficult to look for a balance between a retention of employees in their positions and providing opportunities for their further development in the organization; in the organization there is a high fluctuation, mainly in the most important segments of workforce; 'best practice' programs have been implemented in the field but any significant changes cannot be seen in the approach to the employees; organization's customers pass from the organization to competition thanks to earlier personal relationships with former employees; it is expected that in the future a considerable organizational growth will occur or the acquisition requiring a presence of experienced employees will be materialized; restructuring initiated by organization's needs will happen and etc.

The main benefits resulting from a correctly set and applied system of talent management are as follows - talented employees contribute to a more considerable extent to the fulfillment of organization's strategy and economic goals; costs of fluctuation and acquirement of new employees drop; the organization becomes a sought after and attractive employer; talented employees are identified and retained; succession planning for key positions is more efficient as well as ensuring of employees from the internal sources and their motivation; talented employees are appointed to appropriate positions and their potential is better used; losses connected with vacant key positions are minimized.

\section{Processes of talent management}

The efficient work with talents is based on building talent management strategy that will be in line with organization's philosophy and business strategy (see Figure 1) [4, 10]. Only from that strategy and through the strategy of human resources management key decisions can originate suggesting whether and which activities of talent management should be implemented.

Figure 1 Relation between organization's business strategy and a talent-pool

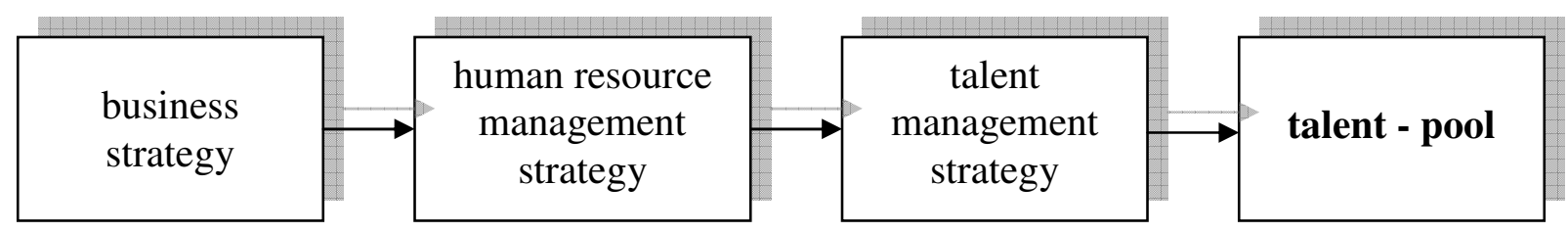

Source: own processing

Strategy of talent management is aimed at ensuring a fund of highly talented, competent, committed and loyal individuals able to contribute to achieving the current as well as future organization's requirements, a so-called talent-pool. 
Three basic groups of processes leading to ensuring an adequate talent pool is a practical outcome of talent management strategy. It is acquisition, development and retention of talents. Each of these processes includes in itself a whole number of related activities, a number of particular elements.

Talent management will be successful only on condition that it is connected with the internal and external recruitment, educating and development of talents, their rewarding, evaluation, motivation, leadership and internal communication.

Organizations differ in ways of how they manage their talents. The ideal approach is to interlink all activities or at least most of them, which is what some organizations are really striving for [1]. Some firms, however, concentrate on one or two activities only, which is not the idea of a systematic approach to talent management.

\section{Talents acquisition}

The first step the organization has to take is to identify key roles. These are such positions in the organization which, if they are not filled, may seriously disturb working of the organization as these roles are the most critical for achieving its success. In connection with that the organization has to assess whether there are available employees with key competencies who will be needed in the future in dependency with business strategy. As long as it has not sufficient existing resources then it has to find these talents. It may identify them among its present employees, from the internal resources or obtain them from the external resources, from labor market, by transferring of talents from competitive firms, from other branches, scouting of talents among employees who have got research fellowship in the organization, by scouting for talented individuals among students or graduates, by direct addressing the chosen individuals, by means of the Internet, specialized agencies and the like.

Organizations should realize that to have a success in the field of talent management is not mainly based on how many talents and what talents they have acquire in competition with other organizations (from external resources) but mainly how they will be dealing with talents they have already got (from internal resources), how they will motivate and develop them and in what way they will take care for them and whether they will respect them, and to what extent they will retain them [6].

An important step that the organization has to take in talent management is to identify key competences of the organization, which are competences crucial for the success of every employee and thus of the whole firm. Maximum of 30 key competences exist, a majority of organizations employs in talent management something between nine and eleven competences [2]. This may be e.g. orientation on activity, communication, creativity and critical judgment, orientation to a customer, interpersonal skills, leadership, team work or technical qualifications.

The identification of talents is made on the basis of assessment of their current performance and a forecast of their potential. Performance appraisal is the measurement of actually achieved results within those areas for which the specified individual is responsible, and/or competencies understood as critical for the success of performed work as well as of the entire organization. A forecast of potential is a prognosis for how many levels within the organization an employee can advance on the basis of their past/current performance appraisal, training and development, preferences in their careers and the current and planned levels of competencies. 
There are a number of methods the organization can use for performance appraisal and a forecast of employees' potential both from the internal and external sources i.e. methods serving to the identification of talents. For a certain type of employee it is always necessary to choose such kinds and combinations that would lead both to performance appraisal and a forecast of potential. It is not possible to rely on one method only. It should also be born in mind that first it is necessary to know the criteria of identification and only then we can choose methods.

Talents from own sources are usually sought for through a working system of regular appraisal within which a number of methods are utilized. To the most used methods belong the method of assessment according to set objectives (MBO - Management by Objectives), assessment centre, the analysis of critical events, and a $360^{\circ}$ feedback. In order to identify talents from the external sources the tests of fitness, a method of assessment centre and behavioral (competent) talks can be used.

After performance appraisal and a potential forecast, the very group of talented employees is specified - a talent-pool is formed. Individuals meeting in advance determined criteria can be jointly indicated as talents or this group of talented individuals can be furthermore divided into three groups - top talents, talents and potential talents (see Figure 2). It always depends on the organization and its approach to the classification of talents.

Figure 2 Classification of talents

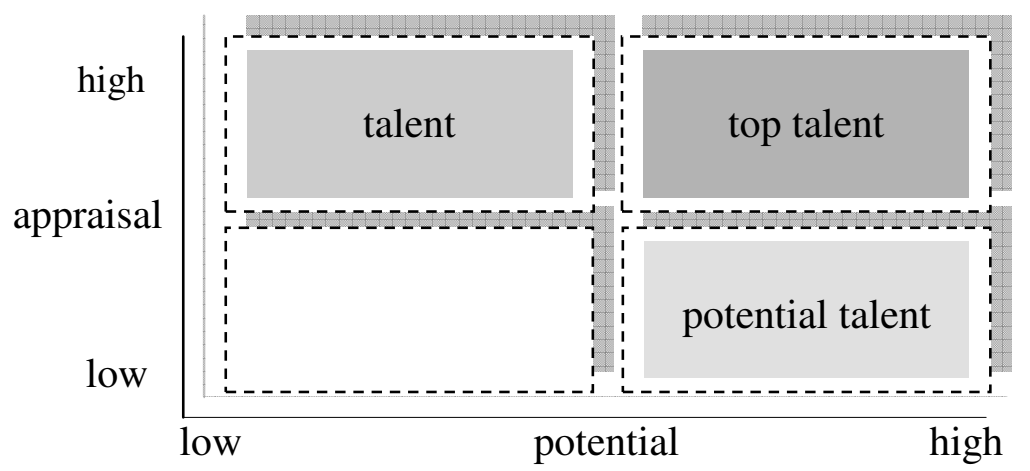

Source: CANNON, J. A.; McGEE, R. Talent management and Succession Planning. 1st ed. London: CIPD, 2007. 406 p. ISBN 978-1843981732.

\section{Talents development}

As for further talent development the organization should offer those individuals a possibility of their strong points development, the improvement of individual total performance as well as of particular competences, strengthening their motivation and making the development of their career possible.

For talented employees, a special development plan should be materialized in a close cooperation with their managers that should have a shape of the integral program for the exactly specified group of talents supplemented by particular participants' individual needs.

A development program may include a combination of various methods, activities or instruments of talents development but always according to the specific needs of the concrete organization. The methods employed are both the methods used to the development at a workplace at job performance (on-the-job) and the methods used to the development 
outside a workplace (off-the-job). A greater emphasis is laid on methods used for education at a workplace but, of course, both groups of methods are used.

According to the Deloitte Company's survey and the experience from international companies that have already applied talent management, the most efficient way of talent development are methods of on-the-job or learning directly at a workplace, mainly cross-training and the involvement in projects with the support of a manager, couch or mentor.

Programs of talent development are very closely connected with career planning and succession planning. They provide talents with opportunities to grow in their current job roles and to move forward to the roles of a higher level. Career planning shapes the advancement of talents in the organization in compliance with the judgment of organizations' needs. Talented people should go through a certain sequence of experience supplemented by couching and development programs that will prepare them to be ready to occupy more demanding job roles in the future. Succession planning is to ensure that the organization will have to its disposal talents that it will need to satisfy its business needs in the future.

\section{Talent retention}

Also activities ensuring retention and stabilization of talents in the organization are inseparable part of talent management. Talented individuals should not leave the organization because their departures have usually extraordinary impact on organization's operation, which is irrelevant to their number. Among factors influencing talents retention in the organization there are the offer of interesting and valued work, ensuring opportunities for education and development, and professional advancement, respecting a balance between professional and private life, the offer of a flexible work role, the offer of a quality work conditions and equipment, provision of sense of recognition and respect, the offer of adequate remuneration and recently also gaining grounds for organization's social responsibility approach.

\section{The use of talent management by organizations in the Moravian-Silesian Region}

To confirm or refute the assumption of a rather lower level of talent management use by Czech organizations and also to find out further information on all aspects of this approach application in practice, a survey of talent management use in one of Czech Republic regions, in organizations of the Moravian-Silesian Region has been carried out by author of this article. There is an assumption that the level resulting from the survey having been carried out in that region might be roughly analogous also in other regions of the Czech Republic with the exception of the capital of Prague area, and probably also the area of the Central Bohemia Region. Of course, to obtain a comprehensive view of the issue of talent management use, the survey would have to be carried out in organizations within the whole Czech Republic at best or as a supplement of already carried out survey in organizations of the Moravian-Silesian Region, in the capital of Prague and in the Central Bohemia Region. This would be, however, a more extensive investigation and that is why the author focused on one region only.

The content of the survey was to map the issue of talent management use in human resources management in organizations of the Moravian-Silesian Region. The aim of the survey in particular organizations was to find out not only the extent, content, importance and benefits of talent management use but also interested persons' response to the implementation and use of talent management, causes why talent management was not used or used unsuccessfully in its application, kinds of instruments applied to particular regions of human resources 
management (job performance assessment, development and education, motivation and retention of employees, career management) and the impact of the current economic crisis on the use of talent management.

As a method of survey the electronic inquiring was chosen by means of in advance formulated questionnaire the part of which was also a covering letter. The questionnaire included a total of 25 questions, 20 of them concerned the solved issues and 5 questions were identification.

To work out a set of respondents within which the survey was carried out, a procedure of three-stage choice was chosen. As a basic set, a group of all organizations (registered units) having their seat in the Moravian-Silesian Region was chosen. In the first stage of the choice, a selective set of the size of 300 respondents from the basic set was worked out by the technique of quote choice; quotes had been made in such a way that in the selective choice a percentage representation of the organization's addressed groups according to the prevailing activities (branches) correspond with a percentage representation of specified prevailing activities (branches) in the basic set where needed data was obtained from the MoravianSilesian Region Statistic Yearbook 2008. A quota choice, as it is often usual in practice, was applied for the reason of being based on a prerequisite that as soon as characterizations of the basic set are known and the selective set fulfills them, then this set will be a representative one [9].

In the second stage of the choice the set of respondents was then worked out within particular quotas by the technique of random choice (by means of a generator of random numbers).

Covering letters including a reference to the questionnaire were distributed by e-mail at the beginning of September 2009. From the total number of $300(100 \%)$ of sent questionnaires $37(12.3 \%)$ of them returned completed (6 organizations used talent management, 31 did not use it), 12 questionnaires (4\%) returned as undeliverable and 251 questionnaires $(83.7 \%$ ) did not return. As a return of distributed questionnaires was relatively low (from the total number of 300 distributed questionnaires only 37 of them returned completed, which was $12.3 \%$ ). For the purpose of obtaining such a number of responses that would make the formulation of relevant conclusions possible, the author of the article decided to perform another round of a survey. In that second round an inquiring via telephone was chosen as a method of a survey, respondents were asked questions identical with the questions used in electronic inquiring.

Telephone inquiring took place in the second half of November 2009. Altogether, 300 identical respondents $(100 \%)$ were addressed as in the case of written inquiring with the result that with 37 respondents $(12.3 \%)$ who had completed electronic questionnaire the inquiring on the phone was not realized (after finding out that a respondent had already completed the electronic questionnaire a telephone call was finished), 200 respondents $(66.7 \%)$ answered questions of telephone inquiring (3 of them used talent management, 197 did not use it) 39 respondents $(13 \%)$ did not answer the questions of telephone inquiring for the reason of being busy or for some other reasons it was not possible to get into a telephone contact with 24 respondents ( $8 \%$ ), (maximum of 3 attempts were made).

On the basis of both rounds realization, both written and by means of a telephone call it can be said that 237 respondents $(79 \%)$ answered questions included in the questionnaire and 63 respondents $(21 \%)$ did not answer them. The set of responses from 237 respondents 
(79\%) can be considered as meeting requirements for the formulation of relevant conclusions resulting from the evaluation of responses to questions in the questionnaire.

After checking of all electronic questionnaires completeness and the completeness of recorded responses to all telephone inquiring, follow-up processing of obtained data was carried out. On its basis it can be said that talent management is applied by organizations in the specified region to a small extent; this approach is used by $3.8 \%$ of organization, that is 9 from $237(100 \%)$ of respondents who answered questions included in the questionnaire. On the other hand, however, the use of talent management by a minimum number but at least some number of respondents shows that the specified approach is not completely unknown as it has been until recently.

From 9 organizations using the approach of talent management, 3 of them rank among medium (from 51 to 250 employees) and 6 of them rank among large (over 250 employees) organizations, they mostly ( 8 organizations) operate for a longer period (from 10 up to 15, and more than 15 years), their prevailing activity (branch) is manufacturing industry ( 3 organizations), civil engineering ( 2 organizations) and accommodation and catering ( 2 organizations). But there can be found also organizations performing other activities, operating in other industries (trade and repairs, activities in the field of real estate and renting; business activities). A majority of those organizations, 6 of them, started to use talent management in the horizon of the last 5 years, only in one case the period of utilization of that approach is longer than 5 years and 2 organizations use talent management less than two years. As far as a legal form is concerned, in 6 cases these are commercial companies, the rest of 2 subjects are private entrepreneurs. Among organizations using talent management, cooperatives or state-owned companies are completely missing. A majority of those organizations, 7 of them, is owned by a foreign owner (a shareholder). That is why it is partly possible to explain why those organizations use talent management - their foreign owner or a shareholder transfers to the Czech environment the approach the benefits of which are confirmed by practice and there is not any reason why they should not, under certain conditions, 'work' also in our business environment.

As a whole, these organizations evaluate the use of talent management as beneficial (6 organizations as very successful and beneficial, 3 organizations as partially successful and beneficial) not only for the organization as such but also for particular employees. All 9 organizations think talent management one of their priorities. As regards a practical application of theoretical knowledge, conditions of efficient working of that approach - talent management is in all 9 organizations initiated and supported by organization's management, in majority of organizations, in 7 of them, have a worked out strategy of talent management that is there linked with organization's business strategy. In all 9 organizations talent management is really seen as a systematic and complex implementation of all three processes of that approach - acquisition, development and retention of employees in the organization. Reactions of the involved people to the implementation and the use of talent management were positive in those organizations.

And how does the current economic crisis impact on organizations using talent management? Two thirds of respondents ( 6 organizations) mentioned that in their case the current economic crisis had no impact on the field of talent management use. They state that talent management is still considered a priority in their organizations, they consider this approach a key investment to the future or that their business activity has not been hit by the crisis so far. Remaining one third of organizations ( 2 organizations) are experiencing a certain impact of 
the current economic crisis on the use of talent management - a certain review of the purposefulness of the present system of talent management costs is being taken place or the budget intended for talent management has even been cut (or some its parts, for example the one intended for development and education). In comparison with the study The War on Talent? Talent Management under Threat in Uncertain Times [11] which was worked out by the CIPD organization in November 2008 among 705 respondents - CIPD members, executives in organizations working both in a public and private sector, in profit and nonprofit organizations we can say that the findings obtained on the basis of a questionnaire survey in organizations of the Moravian-Silesian Region are relevant to the conclusions published in the mentioned study - there are both organizations that do not experience the impact of the crisis, they still consider talent management a priority and key investment in the future, and organizations that have experienced the impact of the crisis on their working, which reflected mainly in reassessing the purposefulness of the existing system of talent management costs or directly in cut in the budget for the whole talent management or at least its part.

Organizations that do not use talent management, 195 of them are small (up to 50 employees), 19 are medium (from 51 to 250 employees) and 14 are large (over 250 employees) organizations. They operating for various time, from a period of less than 2 years ( 2 organizations) up to more than 15 years (96 organizations), their prevailing activity (branch) is commerce; repairs of motor vehicles and products for personal consumption and mostly for households (88 organizations). We can see there, however, organizations performing other activities, operating in other branch (activities in the area of real estates and renting; business activities, civil engineering, public, social and personal services, manufacturing industry and others). These organizations in most cases (215 organizations) do not have a foreign owner (shareholder), which may influence why they do not use talent management. In case they have got him, a foreign owner or a shareholder could transfer by a practical experience verified approach into the Czech environment. As for legal status of organizations that do not use talent management we can find there all four types - trading companies (176 organizations), private entrepreneurs (41 organizations), 2 cooperatives and 9 state companies; commercial companies, however, prevail.

As the main reason why organizations do not use talent management they state that they are not familiar with it; this reason was mentioned in 118 of 228 organizations not using talent management, which can be understood as a negative finding. In case organizations are familiar with talent management then they consider as an essential reason why they do not use it lack of sources necessary for talent management application, both financial (36 organizations) and personnel (33 organizations). Some respondents think that the specified approach is too demanding as regards their organization (23 organizations) or unsuitable for it (10 organizations), other organizations ( 8 organizations) mention as a reason why they do not use talent management a small size of their organization, its short history or low confidence in talent management as a new approach (see Figure 3).

On the basis of the above-mentioned can we determine the main factor, or possibly the main factors conditioning whether this approach is used or not?

A prevailing activity (branch) is not the factor that influences whether talent management is used or not, because a majority of activities the organizations are dealing with and use talent management can be also found in organizations that do not use it. It is similar with organizations in case of organization's legal form because both among organizations using 
talent management and among those that do not apply it, a majority of subjects are commercial companies. What is interesting is the fact that among organizations that do not use talent management there are either cooperatives or state-owned companies. On the Figure 3 Reasons why organizations do not use talent management

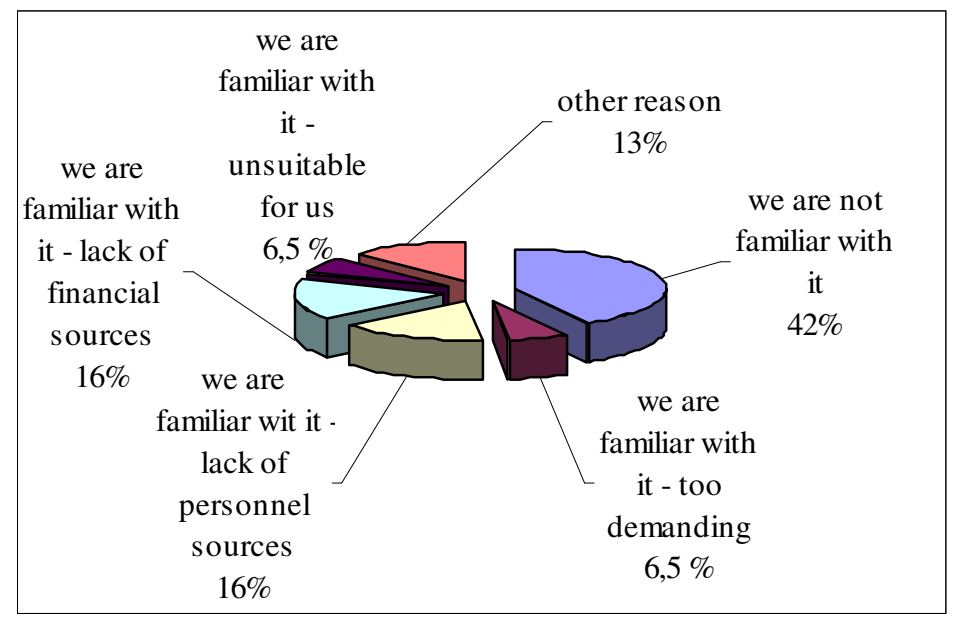

Source: own processing

contrary, among organizations that do not use talent management, organizations of all four legal forms can be found. Even a longer period of organization's working does not influence whether they use talent management or not because organizations whose period of working is from 10 up to 15 and more years can be found in both groups of respondents, both those who use talent management and those who do not apply this approach. It does not hold true that the longer the organization works the more probably is that it will use talent management. Apparently, the truth is that organizations that use talent management first had to build up a certain position on the market during a certain period and then also maintain it, gain stability, competitiveness, be financially strong it means to have sufficient sources and only then decide for the use of talent management. Also such organizations, however, do not have to use talent management necessarily it always depends on organization's concrete situation.

A factor influencing whether talent management is used or not is the existence of a foreign owner (shareholder) - a majority of organizations using it have got a foreign owner (shareholder). This fact can be confirmed by a finding that in a majority of cases the organizations that have not got a foreign owner (shareholder) do not use talent management. Another factor influencing whether talent management is used or it is not is a number of employees in the organization, its size. All organizations using talent management can be ranked to medium ones (from 51 to 250 employees) and bigger (over 250 employees); among organizations that do not use talent management we can find small or medium as well as big organizations, a majority of those respondents, however, falls to the category of small organizations (up to 50 employees).

\section{Recommendations for practice}

On the basis of summarization and systematization of talent management knowledge, the evaluation of this approach drawbacks and benefits, getting acquainted with the practice abroad, and the evaluation of questionnaire survey data obtained in Moravian-Silesian Region organizations it can be recommended to those who use that approach (not only in this region 
but generally in the whole Czech Republic) to continue their activity and in case of certain drawbacks to improve their approach and act as an example of the successful application in the Czech practice and to those who do not use talent management to start using this valuable, beneficial and by foreign practice as well by a number of studies verified approach (of course, relevant to organization's concrete situation).

Since the ignorance of talent management has been identified as a main cause of why it is not used, it is necessary to try to ensure the existence of a sufficient amount of quality and reliable information (awareness) on every aspect of talent management. Chances of how to ensure keeping people informed in the required quality and quantity is available, it is only a question of their practical application. It concerns, for example, ensuring a higher level of information on the existence of the specified approach as such, on its advantages and benefits, positive experience in its application and possibilities of the specified approach in every field of activities, various types of organizations (with the introduction of the existence of certain limits in the approach feasibility taking into account a size of the organization) or on a possibility of its use for various groups of employees (all employees, managers and specialists, managers only, specialists only). In some organizations it would be desired to change a quality of human resources management, to adjust standards of work in the specified field and to try to change a point of view of organization's priorities arrangement towards awareness and taking into account a significant position of human resources management, and thus also the importance of talent management.

A common denominator of all above-mentioned recommendations in the field of a sufficient number of information is a necessity of talent management massive promotion by means of all available instruments. This includes both publishing of professional papers, conference papers or monographs dealing with the specified topic, and giving lectures, organizing seminars, workshops for experts with practical experience. Also including the issue of talent management into curricula of followed master and doctoral study of relevant fields or into MBA study curricula as well as personal promotion of talent management by the representations of organizations successfully using that approach or the involvement of professional associations, e.g. the Club of Czech Republic Personnel Officers and others would be a considerable contribution.

\section{Conclusion}

More and more quick and frequent changes of the external environment make higher and higher demands on organizations [3]. For almost all types of organizations the main asset to manage those changes are people. Without a skilled workforce, without employees equipped by required abilities and knowledge, a number of organizations will not be able not only to keep up with competition but they even may not to survive under specified conditions.

Talent management can be considered as one of fundamental instruments of human resources management in the organization. But what should be the organization's attitude to the management of its talented employees? It should offer them a real perspective and pay attention to the strategy of their management. Not to use only formal programs of talent development and concentrate on career management and succession planning but to apply a comprehensive system of talent management that will enable those talented individuals a real development and a deeper identification with the organization. This system then helps organizations acquire and retain highly talented employees, build on their strengths, reward 
their success, provide them with opportunities for advancement and increase their overall efficiency and thus the efficiency of the whole organization.

Also this article dealt with a possibility of using the system of talent management in human resources management in the organization. The sense of its text was in addition to the description of the essence, content, significance and benefits of that approach to present mainly the processes of talent management - acquisition, development and retention of talents as concrete instruments of systematic work with talented individuals in the organization. The aim was to characterize in detail particular parts of the specified system and to offer instructions how to put partial activities to practice within the framework of acquisition, development and retaining of talents so that these activities really could lead to the survival and growth, to overtaking the existing competition and to a considerable increase in organization's added value. In the final part the level of talent management use by organizations in the Moravian-Silesian Region was described and recommendations for a broader application of that approach in the Czech practice were submitted.

\section{Bibliography:}

[1] ARMSTRONG, M. Řízení lidských zdrojů: nejnovější trendy a postupy. Přel. J. Koubek. 1. vyd. Praha: Grada Publishing, 2007, 789. ISBN 978-80-247-1407-3.

[2] BERGER. L. A; BERGER, D. R. Talent Management Handbook: Creating Organizational Excellence by Identifying, Developing \& Promoting Your Best People. 1st ed. New York: McGraw-Hill, 2003, 450 p. ISBN 978-0071414340.

[3] BORBÁS L.: Contribution of family enterprises to the spatial development in the North Hungarian Region. ERENET Profile, Issue Vol.IV., No.4, October 2009, p. 42 - 48. ISSN 1789-624X.

[4] CANNON, J. A.; McGEE, R. Talent Management and Succession Planning. 1st ed. London: CIPD, 2007, 406 p. ISBN 978-1843981732.

[5] KECLÍKOVÁ, K.; BRIŠ, P. Současné a budoucí trendy v managementu zdravotnictví. Jakost pro život, březen 2007, s. 32-35. ISSN 1213 - 0958.

[6] KOUBEK, J. Řízení talentů - aktuální téma personalistiky. Personál, záŕí 2007, s. 6-7. ISSN 1213-8878.

[7] MIKLOŠÍK, A. Faktory úrovne procesov a procesná optimalizácia. In Aktuálne výzvy teórie a praxe pre obchod, marketing, služby, cestovný ruch a medzinárodné podnikanie. Bratislava: Vydavatel'stvo EKONÓM, 2010. ISBN 978-80-225-3032-3, s. 443-447.

[8] SMILANSKY, J. The Systematic Management of Executive Talent. London: Hydrogen, 2005.

[9] VOKOUNOVÁ, D. Marketingový prieskum ako dôležitý zdroj informácií. In: Marketing v politike. Zborník z vedeckého seminára. Bratislava: 2003. s. 54-68. ISBN 80-225-1767-4.

[10] VOZŇÁKOVÁ, I. Vyznáte se v řeči ekonomů? MM - Průmyslové spektrum - technický měsíčník pro Českou republiku a Slovensko, číslo 9/2009, s. 78 ISSN 1212-2572.

[11] Studie The War on Talent? Talent Management Under Threat in Uncertain Times. Part 1. CIPD (Chartered Institute for Personnel and Development) 2009 [on-line] [cit.200908-12]. Dostupný z WWW:<http://www. cipd.co.uk /NR/ rdonlyres/ DFC760F8-F37C4548-9470-515407 3FE 4EC /0/warontalent.pdf >

\section{Classification JEL: M12, M59}


Ing. Petra Horváthová, Ph.D., Ing. Marie Mikušová, Ph.D.

Odborná asistentka Katedra managementu

Ekonomická fakulta

VŠB - Technická univerzita Ostrava

Sokolská 33, Ostrava 1, 70121

Tel.: 596992442

petra.horvathova@vsb.cz,marie.mikusova@vsb.cz 